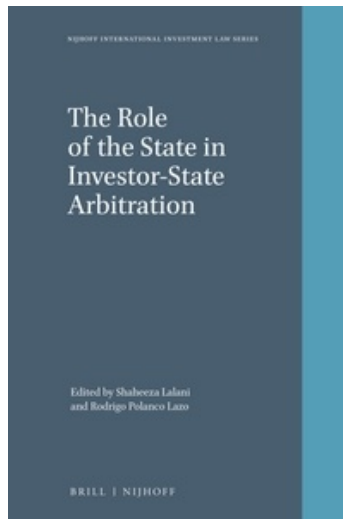

- November 2014

- ISBN: 9789004282247

- Hardback

- List price: $€ 175$ - $^{-}$\$215.-

- Language: English

- Nijhoff International Investment

Law Series, 3

- Imprint: Brill | Nijhoff

Subject

International Law > International Commercial,

Trade \& Investment Law

International Law > International Dispute

Resolution \& Arbitration

International Law > Public International Law

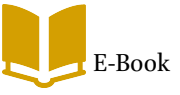

booksandjournals.brillonline.com offers online access to Brill's books and journals.

BRILL

Phone (NL) +31 (o) 71-53 53500

Phone (US) +1-617-263-2323

Email: marketing@brill.com

\section{The Role of the State in Investor-State Arbitration}

\author{
Edited by Shaheeza Lalani, World Trade Institute, University of Bern, \\ and Rodrigo Polanco, World Trade Institute, University of Bern
}

Edited by Shaheeza Lalani and Rodrigo Polanco Lazo, The Role of the State in InvestorState Arbitration is a collection of contributions from lawyers, arbitrators and political scientists on the development of the concept of the "State" in a field that currently presents an increasing number of controversial disputes: Investor-State Arbitration. The book analyzes the limits of the host State as a regulator, studying issues such as attribution and the role of State-Owned Enterprises and sub-State entities; the changing role of the home State in Investor-State disputes, including its direct participation in Investor-State arbitration and State to State dispute settlement; and the overall role that both home and host States can play in the improvement of Investor-State Dispute Settlement.

\section{RE A D E R S H I P :}

All those interested in Investor-State arbitration.

For more information see http://www.brill.com/products/book/role-state-investorstate-arbitration

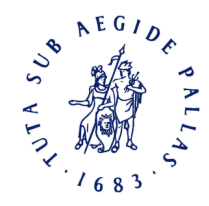

View full information on http://www.brill.com/

B R I L L 